\title{
IAMJ
}

INTERNATIONAL AYURVEDIC MEDICAL JOURNAL

\section{PHARMACOGNOSTICAL AND PHYTOCHEMICAL ESSAY OF BHANDIRA (Clerodendrum infortunatum L.)}

\author{
$\underline{\text { Jijo Jacob }}^{1}$, Subrahmanya $P^{2}$, Ravi Rao $S^{3}$
}

${ }^{1}$ PG Scholar, Dept. of P.G Studies in Dravyaguna Vijnana, AAMC, Moodbidri, D.K., Karnataka, India

${ }^{2}$ Professor and HOD, Dept. of P.G Studies in Dravyaguna Vijnana, AAMC, Moodbidri, D.K., Karnataka, India

${ }^{3}$ Professor, Dept. of P.G Studies in Dravyaguna Vijnana, AAMC, Moodbidri, D.K., Karnataka, India

Corresponding Author: drjijo24@gmail.com

https://doi.org/10.46607/iamj0808092020

(Published online: September 2020)

Open Access

(C) International Ayurvedic Medical Journal, India 2020

Article Received: 21/08/2020 - Peer Reviewed: 11/09/2020 - Accepted for Publication: 11/09/2020

D) Check for updates

\section{ABSTRACT}

The globalisation of Ayurveda and tremendous growth in the population has led to high demand of bio resources. So many medicinal plants mentioned in the Ayurvedic classics are on the verge of extinction. So, there is a need to include new medicinal plants which are less explored to the mainstream. One such plant is Bhandira (Clerodendrum infortunatum L). The drug Bhandira (Clerodendrum infortunatum L.) is a softly tomentose perennial shrub. Bhandira is categorized into the family Lamiaceae. The root of the plant is widely used by folklore practitioners for different disorders. The drug is not much explored in Ayurveda. The pharmacognostic and phytochemical study of the drug reveals the important components of the drug. Hence, present study was undertaken to evaluate pharmacognostic and phytochemical study of the drug Bhandira (Clerodendrum infortunatum L.). In pharmacognostic study the macroscopic and microscopic studies were done. Ash analysis and preliminary phytochemical study also was done. In phytochemical study HPTLC and TLC was carried out. Preliminary phytochemical study of the drug Bhandira (C.infortunatum Linn) showed the presence of Carbohydrates, Flavonoids, Steroids, Resins, Phenolics, Tannins and Triterpenoids. Ash analysis of root of Bhandira (C.infortunatum Linn) showed the presence of Fluoride, Phosphate and Sodium among the inorganic constituents. In HPTLC documentation C.infortunatum root extract showed 7 peaks at $254 \mathrm{~nm}, 8$ peaks at $366 \mathrm{~nm}$ and 11 peaks at $550 \mathrm{~nm}$.

Keywords: Bhandira, Clerodendrum infortunatum L, Pharmacognostic study, Phytochemical study. 


\section{INTRODUCTION}

The drug Bhandira (Clerodendrum infortunatum Linn.) is a softly tomentose ${ }^{1}$ perennial shrub attaining a height of around $1 \mathrm{~m}$ and possessing pinkish white or light purple coloured flowers ${ }^{2}$. It was classified under the family Verbinaceae. But recently it is categorised into the family Lamiaceae ${ }^{3}$. Bhandira is laghu, tikta, ushna, Kaphavata shamaka and has krimighna action ${ }^{4}$. It is indicated in Kushta, Amavata, Jwara, and Krimi ${ }^{5}$. The plant is widely used by folklore practitioners around Alappuzha district of Kerala. Mainly root and leaf of the plant is used by the folklore practitioners for different disorders. Hence the present study was undertaken to evaluate pharmacognostic and phytochemical study drug Bhandira (Clerodendrum infortunatum L.). Clerodendrum infortunatum $\mathrm{L}$ is a large shrub, tomentose. Stem and branches quadrangular. Leaves: opposite, up to $25 \times 20 \mathrm{~cm}$, ovate or suboricular, shortly acuminate at apex, cordate at base, denticulate or serrate, pubescent above, pubescent or tomentose beneath; petiole up to $12 \mathrm{~cm}$ long. Flower: large terminal panicles. Calyx: deeply 5 lobbed, much enlarged in fruit; lobes ovate-acuminate. Corolla: white; tube $2.5 \mathrm{~cm}$ long; lobes lanceolate, subequal. Drupes: bluish black when ripe, enclosed in accrescent calyx. Distribution and Habitat $^{9}$ - Degraded forest areas, moist evergreen forests and plain lands. Found all over India, Srilanka, Myanmar, Andaman \& Nicobar Islands, Thailand, Malaysia, and Bangladesh.

In this study Pharmacognostical analysis of Bhandira (Clerodendrum infortunatum $\mathrm{L}$ ) root was done by macroscopic study and microscopic study, Physiochemical study of Bhandira (Clerodendrum infortunatum L) root, Phytochemical study on Bhandira (Clerodendrum infortunatum $\mathrm{L}$ ) root by Systemic extraction and chemical analysis of the extract, Ash analysis, Chromatographic methods by TLC and HPTLC.

\section{Materials and Methods}

Collection of Sample: The botanically identified and authenticated samples of Clerodendrum infortunatum Linn roots were collected from Alappuzha district in Kerala. Herbarium sample collected and deposited in PG dept. of Dravyaguna Vijnana(AAMC/DG2020/08).
Place of work: Pharmacognostical and Chromatographic study was carried out at Centre of Medicinal Plants \& Research Centre, Kottakkal, Malappuram District, Kerala. Phytochemical study was carried out in P G Department of Dravyaguna Vijnana, Alvas Ayurveda Medical College. Moodbidri.

\section{A) Pharmacognostical study}

1. Macroscopy of Clerodendrum infortunatum Linn Root - The external features of the test sample Clerodendrum infortunatum Linn Root was documented and the organoleptic characters were noted.

2. Microscopy of C.infortunatum Linn Root - C.infortunatum Linn Root was preserved in fixative solution. The fixative used was FAA (Formalin- $5 \mathrm{ml}+$ Acetic acid- $5 \mathrm{ml}+70 \%$ Ethyl alcohol-90ml). The materials were left in FAA for more than 48 hours. The preserved specimens were cut into thin transverse section with a sharp blade and the sections were stained with saffranine. Transverse sections were photographed using Zeiss AXIO trinocular microscope attached with Zeiss Axio Cam camera under bright field light. Magnifications of the figures are indicated by the scale-bars.

3. Powder microscopy of C.infortunatum Linn Root Fine powder of C.infortunatum Linn Root was mounted in Glycerine as well as with phloroglucinol and con.Hcl. Gently heat the mixture and was observed under Zeiss AXIO trinocular microscope attached with Zeiss Axio Cam camera under bright field light.

\section{B) Physicochemical study}

Physical Standards: The air dried roots of Clerodendrum infortunatum L. were powdered finely and subjected to various analysis such as Determination of moisture content ${ }^{10}$, Determination of total ash ${ }^{11}$, Determination of acid insoluble $\operatorname{ash}^{12}$, Determination of water soluble $\operatorname{ash}^{13}$, water soluble extractive value ${ }^{14}$, ethyl alcohol soluble extractive value ${ }^{15}$, methanol soluble extractive value ${ }^{16}$, chloroform soluble extractive value $^{17}$, Acetone soluble extractive value ${ }^{18}$, Petroleum ether soluble extractive value ${ }^{19}$. The extractive value in 
various solvents and ash value are important in identification and standardization of single drugs.

\section{C) Preliminary phytochemical study ${ }^{20}$}

Various tests were conducted to know the presence of Proteins, Carbohydrates, Tannins, Saponins, Flavanoids, Steroids, Alkaloids, Triterpenoides, Starch, Resins, Phenolics, Elagic acid.

Ash Analysis ${ }^{21}$ : The air-dried powdered drug was taken in a crucible and heated in an electric Bunsen burner to make the ash. Then it was diluted with distilled water, boiled and filtered. The solution was tested to know the presence of Carbonates, Fluorides, Chlorides, Sulphates, Chromate, Phosphate, Potassium, Sodium, Aluminium, and Calcium.

\section{D) Chromatographic studies}

1. Thin layer chromatography ${ }^{22}$ : TLC is a technique in which a solute undergoes distribution between two phases, a stationary phase acting through adsorption and a mobile phase in the form of a liquid. A visual comparison of the size and intensity of the spots usually serves for semi-quantitative estimation. Visualisation by Observe the plate under UV light at $254 \mathrm{~nm}$ and $366 \mathrm{~nm}$ and $550 \mathrm{~nm}$ and then record the Rf value and the colour of the resolved bands. Toluene: Ethyl acetate: Formic acid (7: 3: 0.1).

Developing reagent used was Phenol reagent (FCR).

2. HPTLC Fingerprint profile: After development the air-dried plate scanned at $254 \mathrm{~nm}, 366 \mathrm{~nm}$ and $550 \mathrm{~nm}$ after derivatising with anisaldehyde sulphuric acid reagent in CAMAG TLC SCANNER 3 with win CATS software.

\section{Results}

Macroscopic feature of C.infortunatum Linn. Root: The colour of the root were earthy brown and has longitudinal striations. Root were about $12-15 \mathrm{~cm}$ long and $1-2 \mathrm{~cm}$ in diameter.(Fig 1)

Microscopic features of C.infortunatum Linn. Root: T.S of the root is irregular circular in outline, showed cork with phellogen layers. Medullary rays were present in the middle. Powder microscopy of the root of Bhandira showed cork cell fragments, bordered pitted vessel fragments, cortical parenchyma cells, fibres, medullary rays, starch grains, sclerieds.

Physicochemical studies
1. Determination of moisture content: Percentage of moisture content of the drug C.infortunatum Linn. - $6.82 \%$. (Table no .1)

2. Determination of the total ash: Percentage of total ash of the drug C.infortunatum Linn $-4.6 \%$. (Table no.2)

3. Determination of Acid insoluble ash: Percentage of Acid insoluble Ash of the drug C.infortunatum Linn $-1.12 \%$. (Table no.3)

4. Determination of water soluble ash: Percentage of Water soluble Ash of the drug C.infortunatum Linn - $2.2 \%$. (Table no.4)

5. Determination of Extractive values (Table no 5). Phytochemical study

1. Preliminary phytochemistry: The different phytochemical components present in C.infortunatum Linn Carbohydrates, Flavonoids, Steroids, Resins, Phenolics, Tannins and Triterpenoids. (Table no.6)

2. Ash analysis: Ash analysis of C.infortunatum Linn showed the presence of Fluoride, Phosphate and Sodium. (Table no.7)

Thin Layer Chromatography-The photo documentation of the results viewed at $254 \mathrm{~nm}, 366 \mathrm{~nm}, 540 \mathrm{~nm}$. (Fig no.) And HPTLC densitrometric scan at 254nm (Fig no.4), at 366nm (Fig no.4), at 540nm (Fig no.4) were documented.

\section{DISCUSSION}

The drug Bhandira (Clerodendrum infortunatum Linn.) is a softly tomentose perennial shrub attaining a height of around $1 \mathrm{~m}$ and possessing pinkish white or light purple coloured flowers. Bhandira has no references in Brihatrayis, laghutrayis or any nighantus. P V Sharma is the first one to describe the plant Bhandira in his book Dravyaguna Vijnana. Bhandira has Tikta rasa, Laghu ushna sara guna and Kaphavatahara and Pitharechaki action. It is useful in Krimi, Jwara, Kushta, Amavata, Madhumeha, Dushtavrana. The root, leaf of the plant is widely used by folklore practitioners for different ailments.

Pharmacognostical study: Macroscopic Study reveals that the colour of the root was earthy brown and has longitudinal striations. Root were about $12-15 \mathrm{~cm}$ long and $1-2 \mathrm{~cm}$ in diameter. Rootlets are thin and long. 
Roots were found to be hard and woody. T.S of the root is irregular circular in outline, showed cork with phellogen layers. Medullary rays were present in the middle. Stone cells are found to be oval and thick walled. Phloem was parenchymatous and filled with starch grains, xylem vessels are pitted in nature with abundant starch grains. Powder microscopy of the root of Bhandira showed cork cell fragments, bordered pitted vessel fragments, cortical parenchyma cells, fibres, medullary rays, starch grains, sclerieds, prismatic crystals of calcium oxalate and stone cells.

Phytochemical study: Preliminary phytochemical study of the drug Bhandira (C.infortunatum Linn) showed the presence of Carbohydrates, Flavonoids, Steroids, Resins, Phenolics, Tannins and Triterpenoids. Ash analysis of root of Bhandira (C.infortunatum Linn) showed the presence of Fluoride, Phosphate and Sodium among the inorganic constituents. These chemical analyses need more estimation to know the actual number of inorganic constituents present in the plant. Chromatographic study: HPTLC and TLC documentation of drug had been carried out. In HPTLC documentation Clerodendrum infortunatum root extract showed 7 peaks at $254 \mathrm{~nm}, 8$ peaks at $366 \mathrm{~nm}$ and 11 peaks at $550 \mathrm{~nm}$. This data indicates the presence of number of phyto components in the root of Clerodendrum infortunatum Linn.

\section{CONCLUSION}

The drug Bhandira is well known for its folklore use among various folklore practitioners and also mentioned in some of contemporary Ayurvedic texts. The preliminary phytochemical study of the root extract of Bhandira (C.infortunatum L.) shows the presence of Carbohydrates, Flavonoids, Tannins, Triterpenoids, Steroids, Resins and Phenolics. The percentage of hot water extract was higher than all other extracts.Ash analysis of the drug Bhandira (C.infortunatum L.) showed the presence of Fluoride, Phosphate and Sodium. The HPTLC of the drug Bhandira (C.infortunatum L.) root extract showed 7 peaks at $254 \mathrm{~nm}, 8$ peaks at $366 \mathrm{~nm}$ and 11 peaks at $550 \mathrm{~nm}$.

\section{REFERENCES}

1. G K Bhatt, Flora of South Canara,Taxonomy research Centre, Udupi, Page no;488.

2. J L N Shastry, Dravyaguna VIjnana. Chaukambha Orientalia, Varanasi. Page no;893

3. http://www.plantlist.org/angiosperms/lamiaceae/clerodendrum infortunatum.

4. P V Sharma, Dravyaguna Vijnana. Chaukambha Bharati Academy. Varanasy. Page no523.

5. P V Sharma, Dravyaguna Vijnana. Chaukambha Bharati Academy. Varanasy. Page no523.

6. http://www.plantlist.org/angiosperms/lamiaceae/clerodendrum infortunatum.

7. http://indiabiodiversity.org/species/show/251172.

8. G K Bhatt, Flora of South Canara,Taxonomy research Centre, Udupi, Page no;488.

9. http://indiabiodiversity.org/species/show/251172.

10. API, Part 2, Vol 1, The controller of publications, Ministry of H\&FW, Dept of AYUSH, 2004: page no 160.

11. API, Part 2, Vol 4, The controller of publications, Ministry of H\&FW, Dept of AYUSH, 2004: page no 159.

12. API, Part 2, Vol 4, The controller of publications, Ministry of H\&FW, Dept of AYUSH, 2004: page no 159.

13. API, Part 2, Vol 4, The controller of publications, Ministry of H\&FW, Dept of AYUSH, 2004: page no 159.

14. API, Part 2, Vol 4, The controller of publications, Ministry of H\&FW, Dept of AYUSH, 2004: page no 160.

15. API, Part 2, Vol 4, The controller of publications, Ministry of H\&FW, Dept of AYUSH, 2004: page no 160.

16. API, Part 2, Vol 4, The controller of publications, Ministry of H\&FW, Dept of AYUSH, 2004: page no 160.

17. API, Part 2, Vol 4, The controller of publications, Ministry of H\&FW, Dept of AYUSH, 2004: page no 160.

18. API, Part 2, Vol 1, The controller of publications, Ministry of H\&FW, Dept of AYUSH, 2004: page no 144.

19. API, Part 2, Vol 4, The controller of publications, Ministry of H\&FW, Dept of AYUSH, 2004: page no 160.

20. API, Part 2, Vol 4, The controller of publications, Ministry of H\&FW, Dept of AYUSH, 2004: page no 160.

21. API, Part 2, Vol 1, The controller of publications, Ministry of H\&FW, Dept of AYUSH, 2004: page no 144.

22. API, Part 2, Vol 1, The controller of publications, Ministry of H\&FW, Dept of AYUSH, 2004: page no 144. 


\section{Figures}

Fig 1) macroscopy of Bhandira (Clerodendrum infortunatum L)
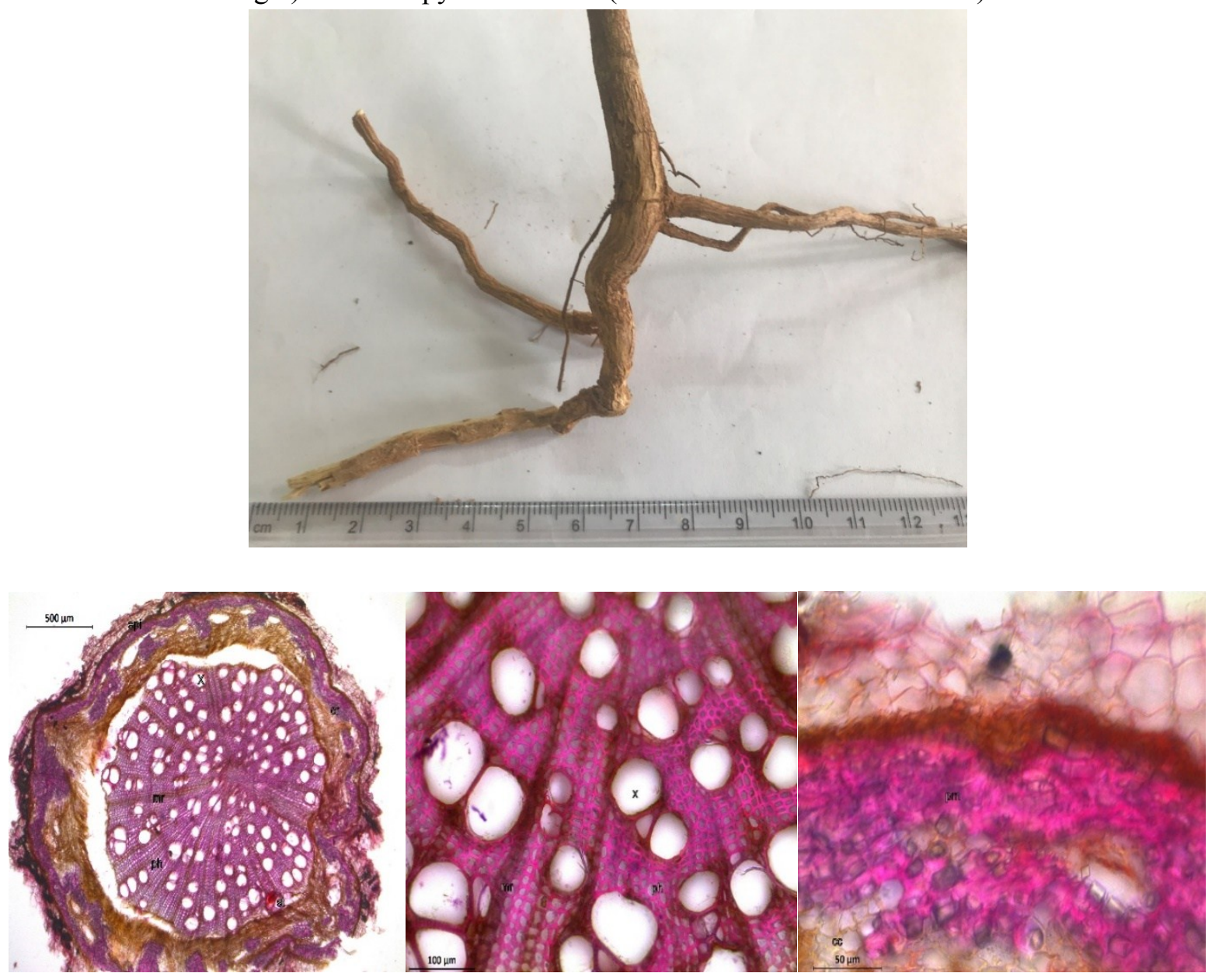

Fig 2 Microscopy of C.infortunatum Linn Root

mr- medullary rays, $\mathbf{x}$ - xylem, ph- phloem, epi- epidermis, cc- cork cell, st- stone cells, pm- parenchyma.
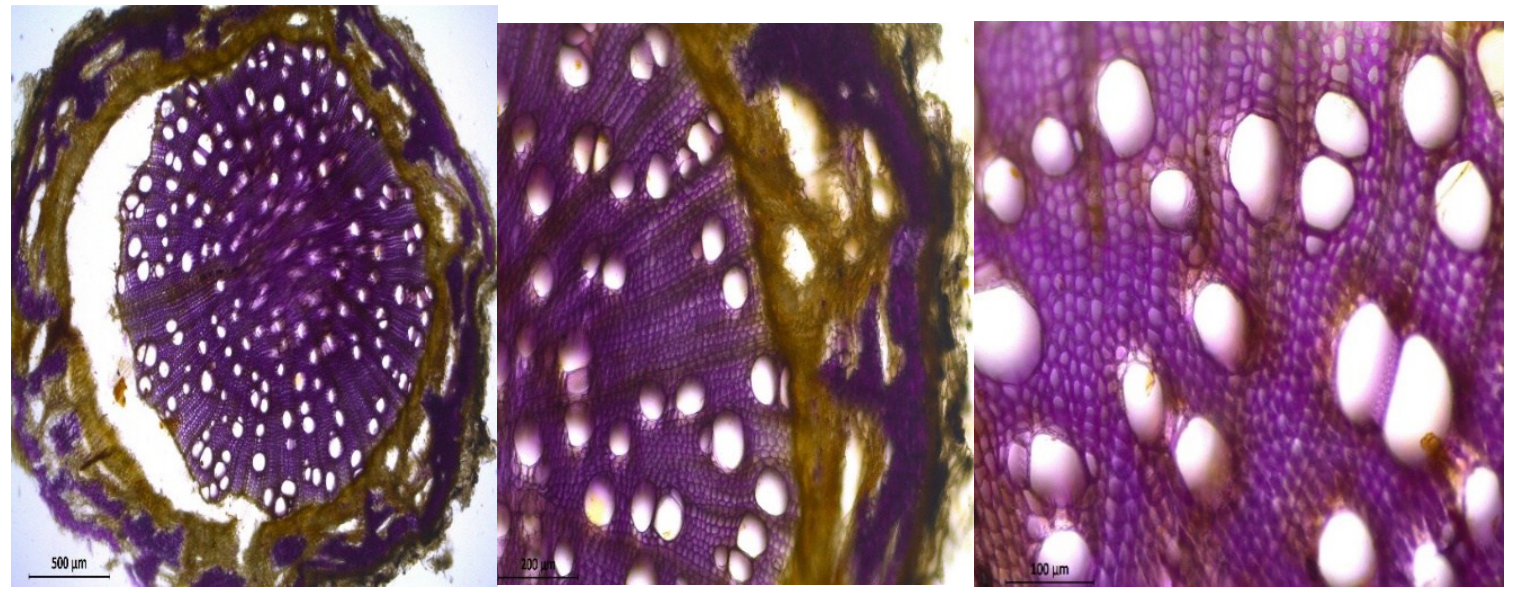
Fig 3) Powder Microscopy of C.infortunatum Linn. Root

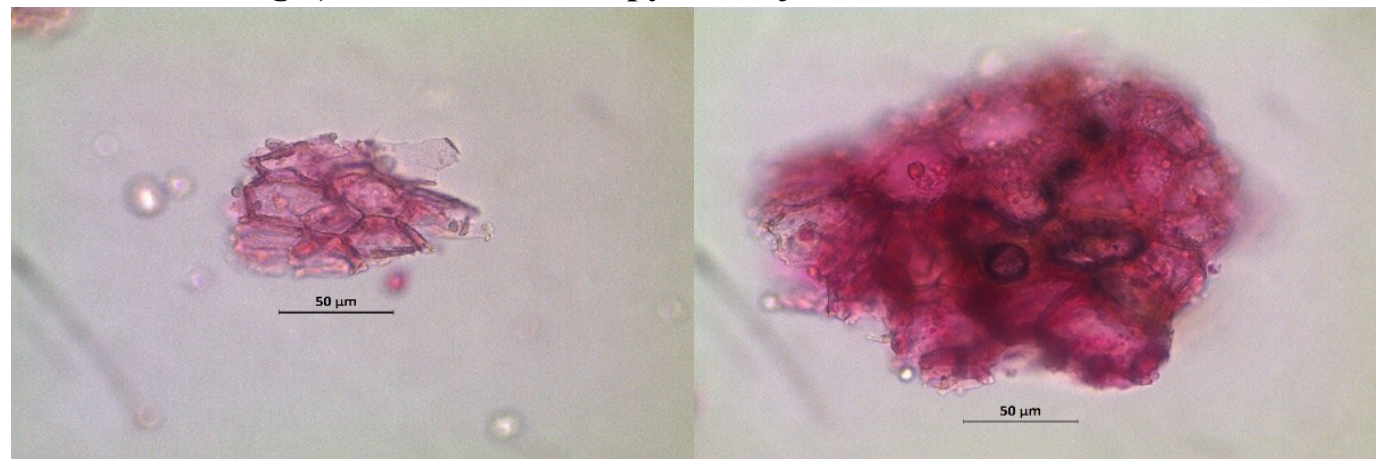

a) cork cells with fragments

b) cortical parenchyma cells

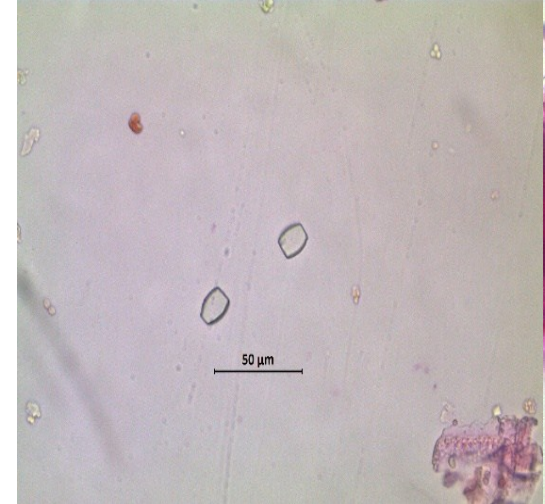

b) prismatic crystal of calcium

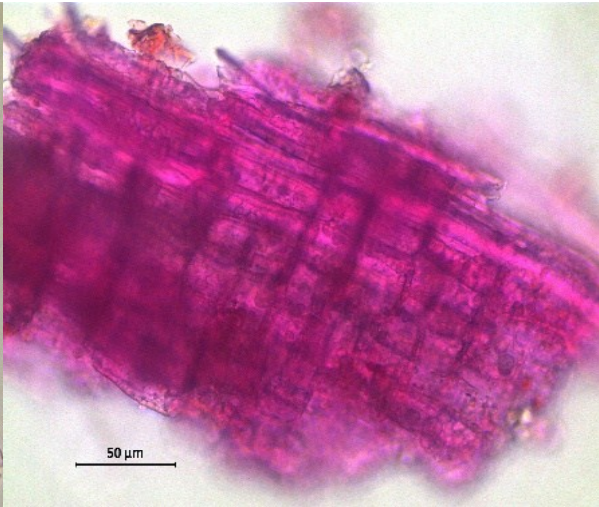

d) fibers and medullary rays

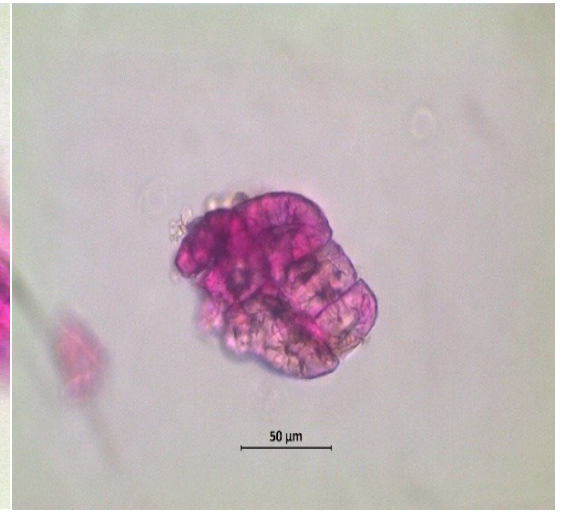

e) groups of stone cells

Fig 4 TLC

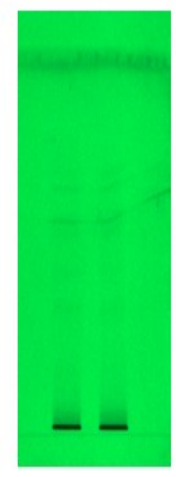

TLC at 250NM

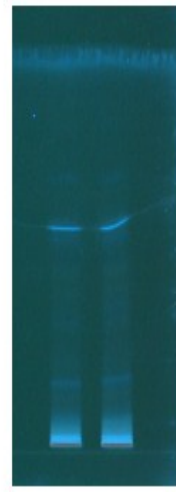

$366 n m$

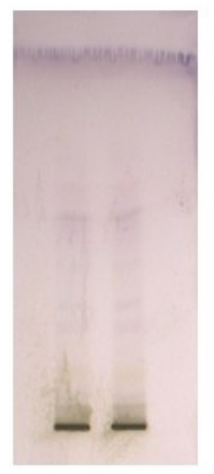

$550 N M$ 
Fig 5 HPTLC at 254nm

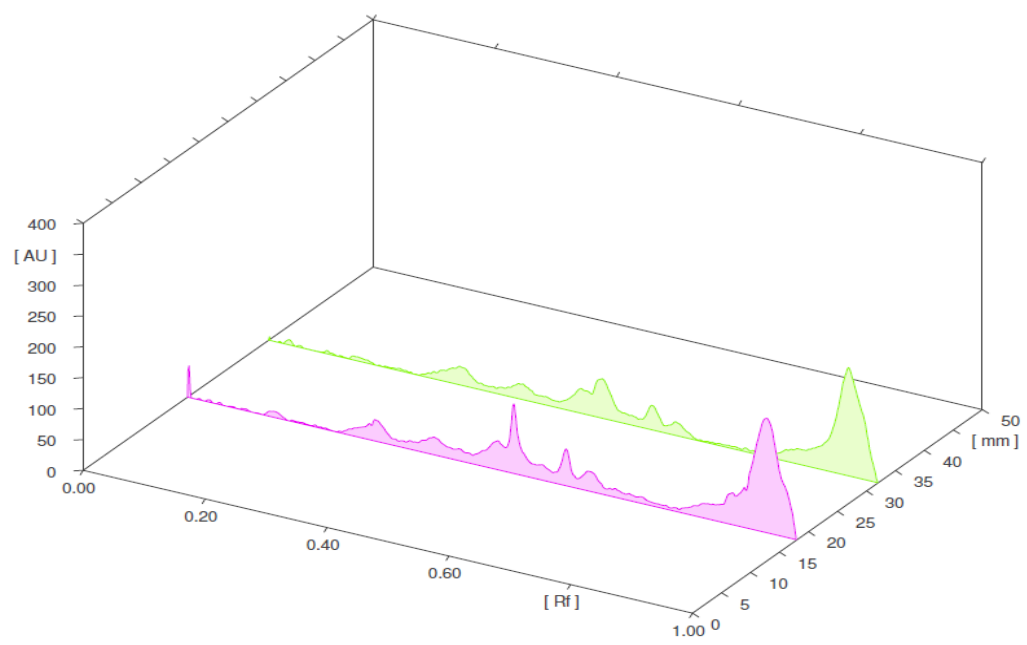

Fig 6 HPTLC at 366nm

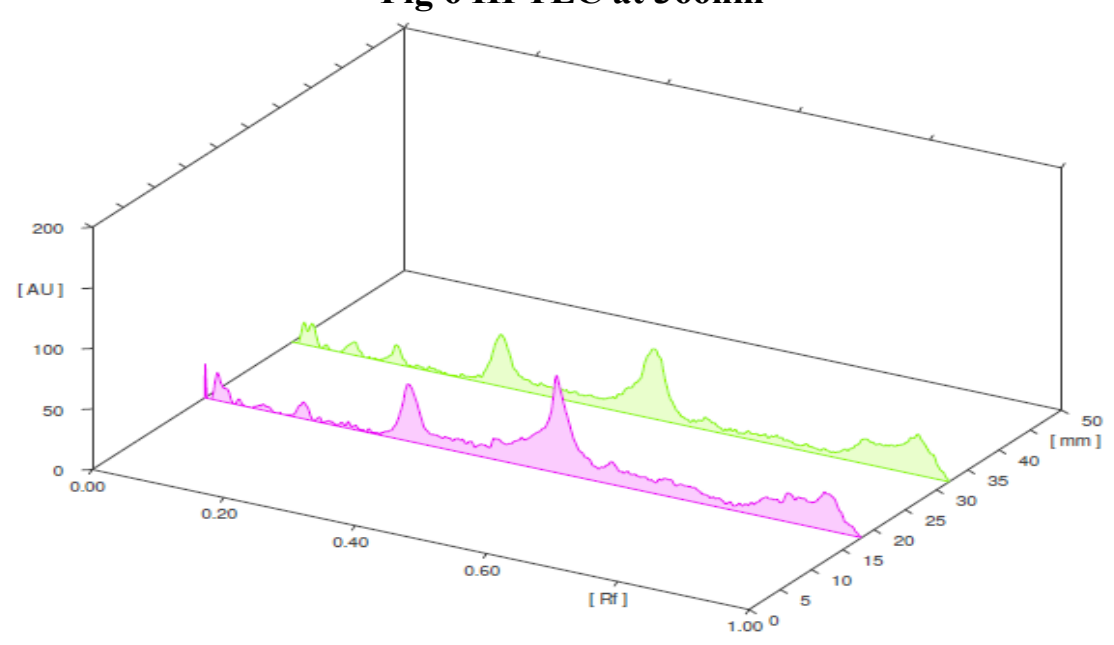

Fig7 HPTLCat550nm

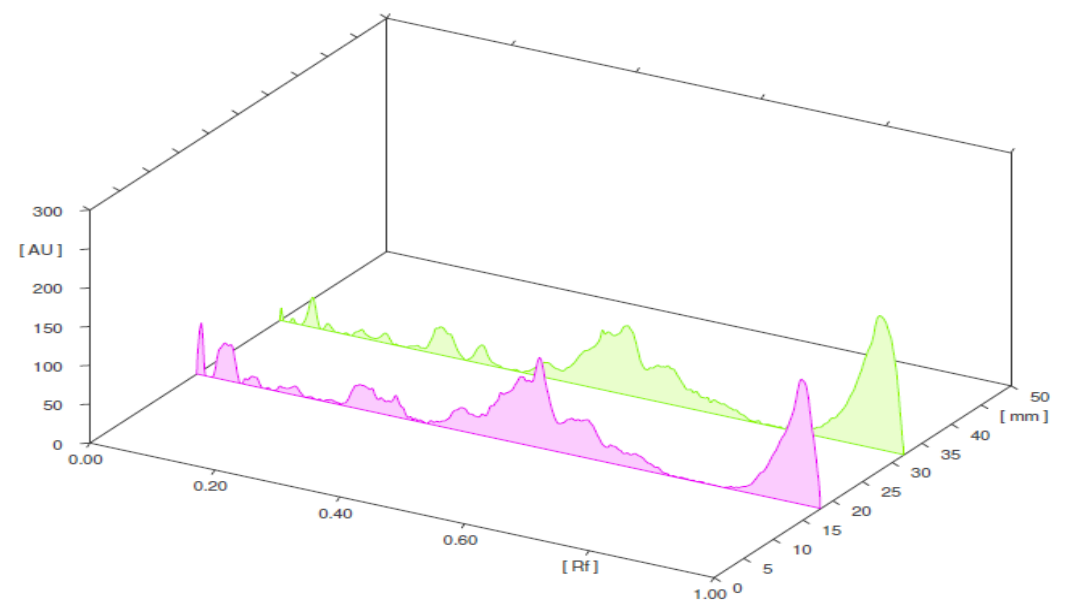


Tables

Table 1: Moisture content of the drugs:

\begin{tabular}{|l|l|l|l|}
\hline Name of Drug & Weight of Drug & Loss of weight after drying & Moisture \\
\hline C.infortunatum Linn. & $5 \mathrm{gm}$ & $0.341 \mathrm{gm}$ & $6.82 \%$ \\
\hline
\end{tabular}

Table 2: Percentage of total ash:

Name of Drug

C.infortunatum Linn.

\begin{tabular}{|l|l|l|}
\hline Weight of Drug & Weight of Ash & Total Ash \\
\hline $5 \mathrm{gm}$ & $0.230 \mathrm{gm}$ & $4.6 \%$
\end{tabular}

Table 3: Percentage of Acid insoluble ash:

\begin{tabular}{|l|l|l|l|}
\hline Name of Drug & Weight of Drug & Weight of acid insoluble & Acid insoluble ash (\% w/ \\
\hline C.infortunatum Linn. & $5 \mathrm{gm}$ & $0.056 \mathrm{gm}$ & $1.12 \%$ \\
\hline
\end{tabular}

Table 4: Percentage of Water-soluble ash:

\begin{tabular}{|l|l|l|l|}
\hline Name of Drug & Weight of Drug & Weight of Water-soluble ash & Water soluble ash (\%w/w) \\
\hline C.infortunatum Linn. & $5 \mathrm{gm}$ & $0.110 \mathrm{gm}$ & $2.2 \%$ \\
\hline
\end{tabular}

Table 5: Percentage of extractive values of drugs in different solvents:

\begin{tabular}{|l|l|}
\hline The Extractive Values In Different Solvents & Percentage of Extract of C.infortunatum Linn. \\
\hline Water & $17.2 \%$ \\
\hline Ethanol & $1.04 \%$ \\
\hline Methanol & $8.58 \%$ \\
\hline Chloroform & $1.5 \%$ \\
\hline Petroleum Ether & $1.04 \%$ \\
\hline Acetone & $1.78 \%$ \\
\hline
\end{tabular}

Table 6: Phytochemical components present in various extracts:

\begin{tabular}{|c|c|c|}
\hline Components & Observation & C.infortunatum Linn. \\
\hline $\begin{array}{l}\text { Proteins } \\
\text { a) Biuret's test } \\
\text { b) Millon's test }\end{array}$ & $\begin{array}{l}\text { No red colour } \\
\text { No white precipitate }\end{array}$ & Absent \\
\hline $\begin{array}{l}\text { Carbohydrates } \\
\text { a) Benedict's test } \\
\text { b) Fehling's test } \\
\text { c) Molisch' test }\end{array}$ & $\begin{array}{l}\text { A coloured precipitate } \\
\text { A red precipitate } \\
\text { A red violet ring }\end{array}$ & Present \\
\hline Tannins & Green colour & Gallo tannins present \\
\hline Saponins & No honeycomb structure & Absent \\
\hline $\begin{array}{l}\text { Flavonoids } \\
\text { a) Shinoda test }\end{array}$ & Pink or reddish-brown colour & Present \\
\hline $\begin{array}{l}\text { Steroids } \\
\text { a) Leibermann-Burchad } \\
\text { b) Salkowski reaction }\end{array}$ & $\begin{array}{l}\text { Greenish colour } \\
\text { Red colour is produced }\end{array}$ & Present \\
\hline $\begin{array}{l}\text { Alkaloids } \\
\text { a) Dragendroff's test } \\
\text { b) Mayer's test }\end{array}$ & $\begin{array}{l}\text { No red precipitate } \\
\text { No white/yellow precipitate }\end{array}$ & Absent \\
\hline Triterpenoides & & Present \\
\hline
\end{tabular}




\begin{tabular}{|l|l|l|}
\hline a) Leibermann-Burchad & Violet coloured ring & \\
\hline Starch & No colour change & Absent \\
\hline Resins & Turbidity present & Present \\
\hline Elagic acid & No red colour & Absent \\
\hline Phenolics & Bluish black colour is formed & Present \\
\hline
\end{tabular}

Table 7: Ash Analysis

\begin{tabular}{|l|l|}
\hline Results of Ash analysis components & C.infortunatum Linn \\
\hline Carbonate & Absent \\
\hline Fluoride & Present \\
\hline Chloride & Absent \\
\hline Sulphate & Absent \\
\hline Chromate & Absent \\
\hline Phosphate & Present \\
\hline Potassium & Absent \\
\hline Sodium & Present \\
\hline Aluminium & Absent \\
\hline Calcium & Absent \\
\hline
\end{tabular}

Table 8: RF values at $250 \mathrm{~nm}$

\begin{tabular}{|l|l|l|l|l|l|l|l|l|l|l|l|}
\hline Track & peak & Start rf & start height & $\max$ rf & $\max$ height & $\max \%$ & end $\mathrm{rf}$ & end height & area & area \% & assigned substance \\
\hline 1 & 1 & 0.25 & 2.3 & 0.31 & 34.5 & 9.42 & 0.34 & 10 & 1249.8 & 13.43 & unknown* \\
\hline 1 & 2 & 0.36 & 10 & 0.4 & 28.6 & 7.79 & 0.43 & 17.7 & 1075 & 11.55 & unknown* \\
\hline 1 & 3 & 0.47 & 13.9 & 0.51 & 47 & 12.81 & 0.52 & 38.7 & 1402.5 & 15.07 & unknown* \\
\hline 1 & 4 & 0.52 & 39 & 0.54 & 112.9 & 30.79 & 0.56 & 22.5 & 1847.5 & 19.86 & unknown* \\
\hline 1 & 5 & 0.6 & 18.6 & 0.62 & 59.6 & 16.26 & 0.64 & 15.2 & 971.8 & 10.44 & unknown* \\
\hline 1 & 6 & 0.64 & 15.8 & 0.66 & 32.2 & 8.78 & 0.69 & 9.9 & 865 & 9.3 & unknown* \\
\hline 1 & 7 & 0.81 & 4.3 & 0.9 & 51.9 & 14.15 & 0.9 & 47.4 & 1892.6 & 20.34 & unknown* \\
\hline 2 & 1 & 0.28 & 10.8 & 0.31 & 29.9 & 13.56 & 0.34 & 9.7 & 1168.5 & 18.5 & unknown* \\
\hline 2 & 2 & 0.39 & 11.4 & 0.42 & 25.3 & 11.46 & 0.44 & 12.7 & 791.9 & 12.53 & unknown* \\
\hline 2 & 3 & 0.48 & 10.1 & 0.51 & 39.9 & 18.08 & 0.53 & 35 & 1202.7 & 19.04 & unknown* \\
\hline 2 & 4 & 0.53 & 35.3 & 0.55 & 64 & 28.99 & 0.59 & 15.9 & 1834.2 & 29.04 & unknown* \\
\hline 2 & 5 & 0.61 & 13.6 & 0.63 & 39.5 & 17.89 & 0.65 & 11.4 & 777.5 & 12.31 & unknown* \\
\hline 2 & 6 & 0.65 & 11.5 & 0.67 & 22.1 & 10.03 & 0.7 & 2.5 & 542.4 & 8.59 & unknown* \\
\hline
\end{tabular}

Table 9: RF values at $366 \mathrm{~nm}$

\begin{tabular}{|c|c|c|c|c|c|c|c|c|c|c|c|}
\hline track & peak & Start rf & \multicolumn{2}{|c|}{ start heigt max rf } & \multicolumn{2}{|c|}{ max heigr max\% } & \multirow{2}{*}{$\begin{array}{r}\text { end } r f \\
0.04\end{array}$} & \multicolumn{2}{|c|}{ end heigh area } & \multirow{2}{*}{\begin{tabular}{|l} 
area \% \\
5
\end{tabular}} & assigned substance \\
\hline 1 & 1 & 0.01 & 1.1 & 0.02 & 23 & 10.85 & & 0.1 & 302.8 & & unknown * \\
\hline 1 & 2 & 0.13 & 1.4 & 0.15 & 13.7 & 6.49 & 0.17 & 0.7 & 194.9 & 3.22 & unknown * \\
\hline 1 & 3 & 0.28 & 4 & 0.31 & 46.9 & 22.15 & 0.34 & 9.5 & 1259.1 & 20.79 & unknown * \\
\hline 1 & 4 & 0.49 & 22.5 & 0.54 & 80.1 & 37.82 & 0.58 & 17.6 & 2892.3 & 47.76 & unknown * \\
\hline 1 & 5 & 0.83 & 6.7 & 0.86 & 16.8 & 7.96 & 0.87 & 15.8 & 434.8 & 7.18 & unknown * \\
\hline 1 & 6 & 0.93 & 20.6 & 0.94 & 31.2 & 14.73 & 0.98 & 9.9 & 972.5 & 16.06 & unknown * \\
\hline 1 & 1 & 0.01 & 0.9 & 0.02 & 18.4 & 8.43 & 0.02 & 11.4 & 136.4 & 2.18 & unknown * \\
\hline 2 & 2 & 0.03 & 12.2 & 0.03 & 18.6 & 8.49 & 0.04 & 1 & 175.8 & 2.81 & unknown * \\
\hline 2 & 3 & 0.08 & 1.5 & 0.1 & 10.9 & 4.98 & 0.11 & 0 & 164.2 & 2.63 & unknown * \\
\hline 2 & 4 & 0.12 & 0.5 & 0.16 & 15.9 & 7.26 & 0.18 & 0.4 & 242.6 & 3.88 & unknown * \\
\hline 2 & 5 & 0.29 & 3.9 & 0.32 & 42.8 & 19.58 & 0.35 & 9.8 & 1238.3 & 19.81 & unknown * \\
\hline 2 & 6 & 0.5 & 14.5 & 0.55 & 57.7 & 26.38 & 0.59 & 6.7 & 2349 & 37.58 & unknown * \\
\hline 2 & 7 & 0.84 & 7.6 & 0.88 & 20.7 & 9.44 & 0.89 & 18.1 & 592.3 & 9.48 & unknown * \\
\hline 2 & 8 & 0.92 & 20 & 0.95 & 33.8 & 15.44 & 0.99 & 7 & 1352 & 21.63 & unknown * \\
\hline
\end{tabular}


Table 10: Rf Values at 550nm

\begin{tabular}{|c|c|c|c|c|c|c|c|c|c|c|c|c|}
\hline track & peak & Start rf & \multicolumn{2}{|c|}{ start heigl max rf } & \multicolumn{2}{|c|}{ max heigt max\% } & end rf & \multicolumn{2}{|c|}{ end heigh area } & area \% & \multicolumn{2}{|c|}{ assigned substance } \\
\hline 1 & 1 & 0.01 & 64.5 & 0.01 & 66.8 & 13.37 & 0.02 & 0 & 267.9 & 1.96 & unknown & $*$ \\
\hline 1 & 2 & 0.03 & 0.5 & 0.05 & 47.5 & 9.51 & 0.07 & 1 & 1115.5 & 8.16 & unknown & $*$ \\
\hline 1 & 3 & 0.07 & 0.2 & 0.09 & 12.5 & 2.5 & 0.11 & 0.1 & 206.5 & 1.51 & unknown & * \\
\hline 1 & 4 & 0.14 & 6.2 & 0.16 & 11.7 & 2.35 & 0.17 & $\mathrm{O}$ & 172.7 & 1.26 & unknown & * \\
\hline 1 & 5 & 0.23 & 1.1 & 0.26 & 31.6 & 6.34 & 0.29 & 17.3 & 1067.7 & 7.81 & unknown & * \\
\hline 1 & 6 & 0.31 & 17.7 & 0.32 & 27.7 & 5.55 & 0.34 & 2.7 & 390 & 2.85 & unknown & * \\
\hline 1 & 7 & 0.39 & 5.3 & 0.42 & 30.2 & 6.05 & 0.45 & 22.7 & 974.8 & 7.13 & unknown & $*$ \\
\hline 1 & 8 & 0.46 & 26.2 & 0.52 & 86.5 & 17.33 & 0.54 & 82.5 & 3805.2 & 27.85 & unknown & * \\
\hline 1 & 9 & 0.54 & 83.4 & 0.55 & 116.2 & 23.26 & 0.58 & 36.6 & 2768.6 & 20.26 & unknown & * \\
\hline 1 & 10 & 0.58 & 37 & 0.63 & 49.7 & 9.95 & 0.66 & 19 & 2435.7 & 17.82 & unknown & * \\
\hline 1 & 11 & 0.69 & 16.1 & 0.7 & 18.9 & 3.79 & 0.73 & 6.8 & 461.3 & 3.38 & unknown & $*$ \\
\hline 2 & 1 & 0.04 & 0.3 & 0.05 & 38.9 & 10.34 & 0.07 & 0.3 & 435 & 3.77 & unknown & * \\
\hline 2 & 2 & 0.12 & 0.2 & 0.13 & 10.9 & 2.89 & 0.15 & 2.9 & 154.3 & 1.34 & unknown & * \\
\hline 2 & 3 & 0.15 & 2.7 & 0.17 & 12.6 & 3.35 & 0.18 & 0.4 & 168.2 & 1.46 & unknown & * \\
\hline 2 & 4 & 0.23 & 3.8 & 0.26 & 36.1 & 9.6 & 0.3 & 0.3 & 1073.9 & 9.31 & unknown & * \\
\hline 2 & 5 & 0.3 & 0.1 & 0.32 & 24.1 & 6.42 & 0.35 & 2.5 & 446.6 & 3.87 & unknown & * \\
\hline 2 & 6 & 0.39 & 0.3 & 0.43 & 19.7 & 5.23 & 0.45 & 13.1 & 618.1 & 5.36 & unknown & $*$ \\
\hline 2 & 7 & 0.45 & 13.2 & 0.52 & 76.8 & 20.45 & 0.54 & 72.7 & 3227.4 & 27.98 & unknown & $*$ \\
\hline 2 & 8 & 0.54 & 73.2 & 0.56 & 89.6 & 23.83 & 0.59 & 37.9 & 2890.8 & 25.06 & unknown & $*$ \\
\hline 2 & 9 & 0.6 & 41.6 & 0.62 & 49.2 & 13.08 & 0.65 & 23.6 & 1930. 1 & 16.73 & unknown & $*$ \\
\hline 2 & 10 & 0.69 & 13.8 & 0.7 & 18.1 & 4.81 & 0.76 & 1.5 & 589.9 & 5.11 & unknown & $\mathrm{O}$ \\
\hline
\end{tabular}

\section{Source of Support: Nil \\ Conflict of Interest: None Declared}

How to cite this URL: Jijo Jacob et al: Pharmacognostical And Phytochemical Essay Of Bhandira (Clerodendrum Infortunatum L.). International Ayurvedic Medical Journal \{online\} 2020 \{cited September, 2020\} Available from: http://www.iamj.in/posts/images/upload/4348_4357.pdf 